\title{
The Effect of Lecturer Commitment on Student Academic Achievement toward Student Satisfaction through Perceived Teaching Quality
}

\author{
Sopiah ${ }^{\mathrm{a}, 1, *}$, Etta Mamang Sangadji ${ }^{\mathrm{b}}$ \\ ${ }^{a}$ Universitas Negeri Malang Jl. Semarang No.5, Sumbersari, Malang, Jawa Timur 65145 \\ ${ }^{b}$ Universitas PGRI Wiranegara Pasuruan, Jl. Kihadjar Dewantara No.28, Pasuruan, Jawa timur 67118 \\ ${ }^{1}$ sopiah.fe@um.ac.id* \\ * corresponding author
}

\begin{abstract}
\begin{tabular}{l|l}
\hline ARTICLE INFO ABSTRACT & ABR
\end{tabular}
Article history

Received July 2, 2019

Revised August 7, 2019

Accepted November 12, 2019

Keywords

Lecturer commitment

Quality of learning

Student satisfaction

The purpose of the study was to examine the direct and indirect effects of lecturer commitments to academic achievement on student satisfaction through perceived teaching quality. The population of this research is all lecturers and students in state and private universities in Indonesia. The research sample used 180 lecturers and 600 state and private university students in East Java, which were obtained by using multi-stage sampling techniques. The main findings of the study prove: 1) There is a positive and significant direct effect of lecturer commitment to academic achievement on perceived teaching quality, 2) There is a significant positive direct effect of lecturer commitment to academic achievement on dental satisfaction 3) There is a significant positive direct effect of perceived teaching quality on student satisfaction, 4) There is a positive and significant indirect effect of lecture-commitment to academic achievement on student satisfaction through perceived teaching quality.

Tujuan penelitian adalah untuk menguji pengaruh langsung dan tidak langsung lecturer commitment to academic achievement terhadap student satisfaction melalui perceived teaching quality. Populasi penelitian ini adalah seluruh dosen dan mahasiswa di perguruan tinggi negeri dan swasta di Indonesia. Sampel penelitian digunakan 180 orang dosen dan 600 orang mahasiswa perguruan tinggi negeri dan swsata di Jawa Timur, yang diperoleh dengan teknik multistage sampling. Temuan utama penelitian membuktikan: 1) Terdapat pengaruh positif dan signifikan langsung lecturer commitment to academic achievement terhadap perceived teaching quality;2) terdapat pengaruh positif signifikan langsung lecturer commitment to academic achievement terhadap student satisfaction 3) Terdapat pengaruh positif signifikan langsung perceived teaching quality terhadap student satisfaction, 4) Terdapat pengaruh tidak langsung positif dan signifikan lecturer commitment to academic achievement terhadap student satisfaction melalui perceived teaching quality.
\end{abstract}

This is an open access article under the $\mathrm{CC}-\mathrm{BY}$ license.

\section{Introduction}

The issue of student satisfaction has been a rigorous study in recent decades. Empirical studies indicate that student satisfaction has a central role and indicators for the sustainability of higher education. Conversely, students who are dissatisfied will become negative promotions that will disrupt the sustainability of the institution/college. Lecturer's commit ment to academic achievement, student satisfaction, and perceived quality has attracted many researchers in the area of Organizational Behavior, HRM, including (Bonney et al., 2015; Duggal \& Mehta, 2015; Elliott \& Shin, 2002; Gee, 2018; Kusumajati et al., 2017; Long et al., 2014; Wamala \& Seruwagi, 2013).

There are many factors that influence student satisfaction/dissatisfaction, including lec- 
turer commitment on student achievement (Xiao \& Wilkins, 2015), student confidence (Gee, 2018), clarity of objectives to be achieved by students (Akareem \& Hossain, 2016; Butt \& ur Rehman, 2010; J. A. Douglas et al., 2015). (Butt \& ur Rehman, 2010) prove that the commitment of lecturers on the achievement of students' academics affects student satisfaction. (Xiao \& Wilkins, 2015) explain the positive relationship of the lecturer's commitment on academic achievement to student satisfaction through perceived teaching quality.

In Indonesia, research on this theme has been carried out by (Prasetyaningrum, 2009). (Warta et al., 2013) examined students in Bali and concluded that service quality (services provided by lecturers) affected student satisfaction. (Nastiti, 2015) researched students in Bandung, proving that student satisfaction was in the current category, lecturer teaching services were in the high category, and the use of learning facilities was in the medium category. Lecturer teaching services and the use of learning facilities by lecturers have a significant effect on student satisfaction. (Nahan, 2013), proving the quality of learning shown by lecturers (such as preparing lectures, mastering media and learning technology), is open to communicating with students and the ability of lecturers to provide examples of the interrelationships between the areas of expertise taught with the context of life can increase student satisfaction. (Yuniarti, 2014) proves that there is a significant influence on the quality of services (including services provided by lecturers) on student satisfaction. Partially (reliability contributed $19.98 \%$, responsiveness $23.25 \%$, physical evidence $25.34 \%$, empathy $21.57 \%$, and guarantees 18.10\%). (Suwandari, 2013) proves organizational commitment, including lecturer commitment to student success) positively influences satisfaction. (Basriani, 2016), researching in Pekanbaru, concluded that lecturer competencies and lecturer commitments influence student satisfaction.

The Indonesian Central Statistics Agency (2019) informed that the number of students enrolled in state and private universities (1997 2019) experienced a significant increase. In 1997 the number of students enrolled at tertiary institutions was still around 1 million. In 2018, it became 6 million students, and in 2019 it reached 7 million students. The addition of the number of students shows that the interest of the younger generation to study in Indonesia is very high. The question is whether the in- creased interest in continuing studies in higher education is also followed by the better quality of the management of learning in higher education? Or are students satisfied with the quality of high education services in Indonesia? This fundamental question needs to be asked to uncover the extent to which an increase in the number of students is as significant as to student satisfaction, which is associated with lecturer commitment to academic achievement and perceived teaching quality.

This study examines the relationship between lecturer commitment variables and student satisfaction directly and indirectly through the quality of learning perceived by students (perceived teaching quality). However, there have been many studies by experts in the fields of Organization-Behavior and education management; the certainty of the relationship between variables is still unclear. There are still many research results that contradict or disagree are the commitment of lecturers to the achievement of academic achievement of student's related influence on dentistry satisfaction directly or indirectly through the quality of learning that is perceived by students?

The novelty of this research is: (1) the level of scope of the research. Most studies are narrow in scope. This research is wider in scope, including 180 lecturers and 600 state and private university students in East Java; 2). Theoretically and empirically, this study seeks to find clarity about the position or linkages between variables, because there are still many different opinions or even conflicting. 3) This research applies the concept of organizational behavior theory/Human Resource Management in the context of higher education. The purpose of this paper is to explain the effect of lecturer commitment (on student academic achievement) on student satisfaction directly or indirectly through the quality of learning perceived by students.

\section{Method}

This study was designed using a quantitative approach and type of explanatory research. This study uses 3 variables, namely: Lecturer Commitment to Academic Achievement (X), Perceived Teaching Quality (Z), and Student satisfaction (Y). The researchers' frame of mind model can be described as Fig. 1 . 


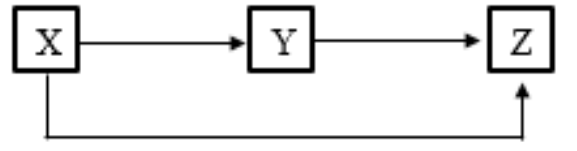

Fig. 1.Research Framework

The study population was all lecturers and students in East Java. With multi-stage sampling, a sample of 180 lecturers and 600 students in East Java was obtained. Data collection in this study was conducted using a closed questionnaire with five alter-native answer choices: strongly agree (score 5), agree (score 4), neutral (score 3), disagree (score 2) and strongly disagree (score 1). The questionnaire, before being distributed to respondents first tested the validity and reliability. A validity test was done by looking at the magnitude of the correlation coefficient (r) $>0.3$ declared valid. All items of 3 variables are declared valid. To measure reliability in this study using the Cronbach alpha test formula. The instrument in this study can be said to be reliable because of the Cronbach alpha value $\alpha$ 0.6. Test the validity and reliability of the instrument used SPSS Statistics Version 16 for windows software.

\section{Results}

Path analysis results show the following results:

A. Direct Effect of Lecturer Commitment on

Student Academic Achievement $(X)$

toward Perceived Teaching Quality (Z)

Based on the regression test that has been done, the recapitulation of the path coefficient results of the influence of the variable $\mathrm{X}$ to $\mathrm{Z}$ can be seen in Table 1:

Table 1. Results of Regression Equation 1 of Variable $\mathrm{X}$ with respect to Z

\begin{tabular}{|c|c|c|c|c|c|}
\hline \multirow[t]{2}{*}{ Variable } & \multicolumn{2}{|c|}{$\begin{array}{c}\text { Unstandardized } \\
\text { Coefficients }\end{array}$} & \multirow{2}{*}{$\begin{array}{c}\begin{array}{c}\text { Standardized } \\
\text { Coefficients }\end{array} \\
\text { Beta } \\
\end{array}$} & \multirow[t]{2}{*}{$\mathbf{t}$} & \multirow[t]{2}{*}{ Sig. } \\
\hline & Beta & Std. Error & & & \\
\hline (Constant) & .984 & .178 & & 5.524 & .000 \\
\hline $\begin{array}{c}\text { Lecturer Commitment to Studet Academic } \\
\text { Achievement }\end{array}$ & .572 & .052 & .434 & 11.072 & .000 \\
\hline
\end{tabular}

a. Dependent Variable: Teaching Quality

Based on the results of the analysis in table 1 we can formulate the regression equation as follows:

Structural Equation 1: $0.434 X+0.782$

e $($ Effect of error $)=$ Variables that are not identified (error) can be calculated as follows:

$$
\begin{gathered}
\mathrm{P} \varepsilon_{1}=\sqrt{1-R_{1}^{2}} \\
=\sqrt{1-0,388}
\end{gathered}
$$

$$
=\sqrt{0,612}=0,782
$$

Based on these calculations $\beta 1 \mathrm{X}=0.434$, sigt $=0,000<0.05 ; \mathrm{H} 1$ received .

\section{B. The Effect of Lecturer Commitment on Student Academic Achievement and Perceived Teaching Quality toward Student Satisfaction.}

Based on the regression test that has been done, the path coefficient results of the variables $\mathrm{X}$ and $\mathrm{Z}$ to $\mathrm{Y}$ can be seen in Table $2 \& 3$.

Table 2. Structural Equation Regression Results 2, the effect of Variables X and Z on Y

\begin{tabular}{cccc}
\hline R & R-Squared & Adjusted R-Squared & Std. Error of the Estimate \\
\hline .694 & .481 & .478 & .175 \\
\hline
\end{tabular}

\begin{tabular}{|c|c|c|c|c|c|}
\hline \multirow[t]{2}{*}{ Variable } & \multicolumn{2}{|c|}{$\begin{array}{l}\text { Unstandardized } \\
\text { Coefficients }\end{array}$} & \multirow{2}{*}{$\begin{array}{c}\begin{array}{c}\text { Standardized } \\
\text { Coefficients }\end{array} \\
\text { Beta } \\
\end{array}$} & \multirow[t]{2}{*}{$\mathbf{t}$} & \multirow[t]{2}{*}{ Sig. } \\
\hline & Beta & Std. Error & & & \\
\hline (Constant) & 1.420 & .093 & & 15.275 & .000 \\
\hline $\begin{array}{l}\text { Lecturer Commitment to Studet Academic } \\
\text { Achievement }\end{array}$ & .087 & .029 & .119 & 3.010 & .003 \\
\hline Teaching Quality & .263 & .021 & .475 & 12.604 & .000 \\
\hline
\end{tabular}

b. Preditors: (Constant), Teaching Quality Lecturer Commitment on Studet Academic Achievement

Table 3. Structural Equation Regression Results 2, the effect of Variables X and Z on Y 
Structure Equation 2:

$$
\begin{gathered}
\mathrm{Y}=\beta_{3} \mathrm{X}++\beta_{2} Z+\varepsilon_{2} \\
\mathrm{Y}=0,119 \mathrm{X}+0,475 \mathrm{Z}+0,720
\end{gathered}
$$

$e($ Effect of error $)=$ Unidentified variables (errors) can be calculated as follows:

$$
\begin{gathered}
\mathrm{P} \varepsilon_{2}=\sqrt{1-R_{2}^{2}} \\
=\sqrt{1-0,481} \\
=\sqrt{0,519}=0,720
\end{gathered}
$$

The effect of $\mathrm{X}$ on $\mathrm{Y}$, equal to $=0.119 \mathrm{X}$, sig $t$ of $0,000<0.05$. Thus, Hypothesis 2 is accepted. Based on Table 2, structure Equation 2:

$$
\begin{gathered}
\mathrm{Y}=\beta_{3} \mathrm{X}++\beta_{2} Z+\varepsilon_{2} \\
\mathrm{Y}=0,119 \mathrm{X}+0,475 \mathrm{Z}+0,720
\end{gathered}
$$

$e($ Effect of error $)=$ Unidentified variables (errors) can be calculated as follows:

$$
\begin{gathered}
\mathrm{P} \varepsilon_{2}=\sqrt{1-R_{2}^{2}} \\
=\sqrt{1-0,481} \\
=\sqrt{0,519}=0,720
\end{gathered}
$$

The effect of $\mathrm{Z}$ on $\mathrm{Y}$ is $+0.475 \mathrm{Z}$, sig $\mathrm{t}$ is $0.000<0.005$. Hypothesis 3 is accepted.

\section{Indirect Effect of Lecturer Commitment} on Student Academic Achievement toward Student Satisfaction through Perceived Teaching Quality

The indirect effect of variable $X$ on variable $\mathrm{Y}$ through variable $\mathrm{Z}$ can be calculated using the following formula:

$$
\mathrm{PTL}=(\mathrm{pz} \times \mathrm{pyz})
$$

Information:

\section{PTL: Indirect Effect}

Pzx: Effect of Lecturer Commitment to Student Academic Achievement (X1) on Teaching Quality $(\mathrm{Z})$

Pyz: Effect of Teaching Quality (Z) on Student Satisfaction (Y), So as:

$$
\begin{gathered}
\mathrm{PTL}=\left(\mathrm{pz} x_{1} \times \mathrm{pyz}\right) \\
=0.434 \times 0.475=0.206
\end{gathered}
$$

Based on these calculations it can be explained that the indirect effect of the Lecturer Commitment to Student Academic Achievement on Student Satisfaction through Teaching Quality ( $\mathrm{Z}$ ) of $20.6 \%$, sig $\mathrm{t}=\mathrm{t}$ of 4.972269268 ( $\mathrm{t}_{\text {count }}>\mathrm{t}_{\text {table }}$ ) which is 1,965 . Thus, Hypothesis 4, which is about Lecturer Commitment on Student Academic Achievement, has a significant positive effect on student satisfaction through perceived teaching quality.

\section{Total Effect}

The effect of the total variable $\mathrm{X}$ on $\mathrm{Y}$ through $\mathrm{Z}$ can be calculated using the following formula:

$$
\begin{gathered}
P T=P_{y x 1}+\left(\mathrm{Pz} x_{1} \times \mathrm{P}\right) \\
P T=P_{y x 1}+\left(\mathrm{Pz} x_{1} \times \mathrm{Pyz}\right) \\
=0,119+(0.434 \times 0.475) \\
=0,119+0.206=0.325
\end{gathered}
$$

Based on these calculations it can be explained that the effect of the total Lecturer Commitment on Student Academic Achievement (X1) on Student Satisfaction (Y) through Teaching Quality (Z) is $32.5 \%$.

\section{E. Total Determination Coefficient}

From the path analysis research model as above, an influence trajectory model can be arranged. The effect of error on each model can be measured using the following formula:

$$
\begin{gathered}
\mathrm{P} \varepsilon_{1}=\sqrt{1-0,388}=\sqrt{0,612}=0.782 \\
\mathrm{P} \varepsilon_{=} \sqrt{1-0,481}=\sqrt{0,519}=0,720 \\
R^{2} \mathrm{~m}=1-P^{2} \mathrm{e} 1 . P^{2} \mathrm{e} 2 \\
=1-(0.782 \times 0.702) \\
=1-0.563 \\
=0.437
\end{gathered}
$$

Based on the results of the Sobel Test, it can be seen the value of $t$ hit is 4,972269268 ( $t_{\text {count }}$ $>t_{\text {table }}$ ) yaitu 1,965. Hypothesis 4 is accepted. 


\section{Discussion}

A. Direct Effect of Lecturer Commitment on Student Academic Achievement toward

\section{Perceived Teaching Quality}

The results prove that the first hypothesis was accepted. This shows that the lecturer commitment to student academic achievement has a significant positive effect directly on perceived teaching quality. The results of this study are supported by the research of (Long et al., 2014), which has proven that the lecturer commitment to academic achievement has a significant positive effect on perceived teaching quality. (Xiao \& Wilkins, 2015) concluded that lecturer commitment to academic achievement had a significant positive effect on perceived teaching quality.

\section{B. Effect of Lecturer Commitment on Academic Achievement toward Student Satisfaction}

Hypothesis 2 which states that lecturer commitment to academic achievement has a significant positive effect on student satisfaction is accepted. This means that if the commitment of lecturers will achieve high student learning outcomes, student satisfaction will be high or increase to be more satisfied.

The results of this study are in line with the research of (Clemes et al., 2001) he conducted a cross-sectional study of 350 undergraduate students at two northwestern university business schools in England. He examined what factors caused students to be satisfied or dissatisfied with the services provided by tertiary institutions in the UK. Satisfaction / dissatisfaction in the field of teaching and learning and learning environment factors and supporting services. The quality of education, campus facilities, and the environment and the educational process has a significant impact on students' perceptions of service quality. Factors of student perceptions of higher education services have an impact on student satisfaction and loyalty to the institution. (J. A. Douglas et al., 2015) concluded in their study that lecturers' commitment to student academic achievement influences student satisfaction. (Xiao \& Wilkins, 2015), the results of their study prove that the lecturer commitment to academic achievement is towards student satisfaction at universities in China. (Djudin, 2018), for the case of students in Pontianak, concluded that the lecturers' commitment to student academic achievement affected student satisfaction. (Basriani, 2016; Nastiti, 2015; Prasetyaningrum,
2009; Suwandari, 2013; Warta et al., 2013; Yuniarti, 2014), prove the commitment of lecturers affects student satisfaction.

\section{Effect of Perceived Teaching Quality on Student Academic Achievement}

Hypothesis 3 which states that the quality of learning perceived by students has a significant positive effect on student learning outcomes is accepted. The quality of operational learning can be interpreted as the intensity of systemic and synergic linkages between lecturers, students, the learning climate, and learning media in producing optimal learning processes and outcomes in accordance with curricular demands (Haryati \& Rochman, 2012). According to Daryanto in (Prasetyo, 2013), the quality of learning is a level of achievement of the initial learning objectives, including learning art, in achieving these goals in the form of increased knowledge, skills, and the development of students' attitudes through the learning process in class. Learning quality indicators are: a. Educator learning (teacher), b. Student behavior or activity, c. Learning climate, d. Learning material, e. Learning media, $f$. The learning system (Ministry of National Education in (Prasetyo, 2013). (Akareem \& Hossain, 2016) examined students in tertiary institutions in Bangladesh, their findings suggesting that students' perceptions of the quality of education, including the quality of learning in higher education, had an impact on student satisfaction in Bangladesh, (Butt \& ur Rehman, 2010), examines the factors that shape student satisfaction in tertiary institutions which lead to student loyalty to tertiary institutions. The results of the study conclude that the factors forming student satisfaction are the image of the forms, student expectations, qualities perceived by students, including the quality of learning perceived by students and other factors are values perceived by students (Temizer \& Turkyilmaz, 2012) conducted a study to measure student satisfaction from various aspects, such as university image, expectations, perceived quality, perceived value, and loyalty The results of his research concluded that was these factors are tested as factors forming student satisfaction. (J. Douglas et al., 2008) conducted a study of 163 undergraduate students at Liverpool John Moores University in England. The results of the study concluded that student perceptions of the quality of learning affect student satisfaction and end on student loyalty. (Al-Kuwaiti et al., 2014; Djudin, 2018; Ganyaupfu, 2013; Jiewanto et al., 2012; Sookdeo, 2016; Suarman et al., 2013; Temizer \& Turkyilmaz, 2012; Tessema et al., 
2012; Wilkins et al., 2012), the results of his study concluded that students' perceptions of quality (including the quality of learning) influence student satisfaction.

\section{Indirect Effect of Lecturer Commitment on Student Academic Achievement toward Student Satisfaction through Perceived Teaching Quality}

Based on the results of the path analysis shows that the commitment of lecturers to the achievement of student academic achievement has a significant positive effect indirectly on student satisfaction through the quality of learning perceived by students. Thus Hypothesis 4 is accepted. Thus it can be concluded that perceived teaching quality acts as a good moderating variable in the relation-ship/influence between lecturer commitment to academic achievement and student satisfaction.

(Xiao \& Wilkins, 2015), research at one of the universities in China. The results of the study concluded that lecturer commitment to student academic achievement and lecturer commitment to student social integration simultaneously had a significant positive effect on student satisfaction. However, lecturers' commitment to student social integration does not affect student perceptions about the quality of teaching. Although the variables are the same, the difference between (Xiao \& Wilkins, 2015) research is that the study only examined one university in China, this study examined eight universities in 6 regions in Indonesia. The indicators for each variable used are also different. The theories on which hypotheses are formulated are also different. The commitment of lecturers has two dimensions, academic and social integration. This study looks at lecturers' commitment to the academic achievement of students only because it is proven by (Xiao \& Wilkins, 2015) proving that lecturers' commitment to student social integration has no effect and is not significant to the quality of learning perceived by students. (Al-Kuwaiti et al., 2014; Sookdeo, 2016; Wilkins et al., 2012), in their research concluded that students' perceptions of quality (including quality of learning) affect student satisfaction.

\section{Conclusion}

Lecturer commitment on student academic achievement is perceived by students in East Java as high. The quality of learning in higher education is perceived by high students. Student satisfaction in East Java is categorized high. Lecturer commitment to student academic achievement has a significant positive effect directly on perceived teaching quality. Lecturer commitment to academic achievement has a significant positive effect directly on student satisfaction. Perceived teaching quality has a significant positive effect directly on student satisfaction. Lecturer commitment to academic achievement has a positive and significant impact on student satisfaction through perceived teaching quality. The results of the study explained that the grand mean of the lecturer's commitment to academic achievement variable included in the high category. Nevertheless, there is the lowest value on the indicator of lecturer commitment to increase student learning motivation on the statement of giving awards to students who are successful in the academic field. It is expected that lecturers will motivate students more by giving awards (can be material or non-material). Student satisfaction includes high or satisfied categories. Nevertheless, students assess the aspirations of students who have not been heard and followed up by university leaders and staff to the fullest. Thus, it is expected that university leaders and staff listen more to the aspirations of students and follow up on them. The quality of learning perceived by students includes high categories. This means that students perceive the quality of learning as good. However, there are still values below the average, namely the ability of lecturers to design instructional media. Understanding the application of instructional media, especially those based on digital in the present era, is already a necessity. Therefore, it is expected that lecturers will continue to learn to design and implement digital-based learning media in learning.

\section{References}

Akareem, H. S., \& Hossain, S. S. (2016). Determinants of education quality: what makes students' perception different? Open Review of Educational Research, 3(1), 52-67.

Al-Kuwaiti, A., Maruthamuthu, T., \& Al Kuwaiti, A. (2014). Factors influencing student's overall satisfaction in Course Evaluation Surveys: An exploratory study. International Journal of Education and Research, 2(7), 661-674.

Basriani, A. (2016). Pengaruh kompetensi dan komitmen organisasi terhadap kepuasan kerja dan kinerja dosen (studi pada yayasan pendidikan persada bunda pekanbaru). Jurnal Tepak Manajemen Bisnis, 8(1), 21-34. 
Bonney, E. A., Amoah, D. P., Micah, S. A., Ahiamenyo, C., \& Lemaire, M. B. (2015). The relationship between the quality of teachers and pupils academic performance in the STMA junior high schools of the Western Region of Ghana. Journal of Education and Practice, 6(24), 139-150.

Butt, B. Z., \& ur Rehman, K. (2010). A study examining the students satisfaction in higher education. Procedia-Social and Behavioral Sciences, 2(2), 5446-5450.

Clemes, M. D., Ozanne, L. K., \& Tram, L. (2001). An examination of students' perceptions of service quality in higher education. Journal of Marketing for Higher Education, 10(3), 1-20.

Djudin, T. (2018). The effect of teaching method and lecture program on students' satisfaction rates and academic achievement. Journal of Education, Teaching and Learning, 3(1), 121-128.

Douglas, J. A., Douglas, A., McClelland, R. J., \& Davies, J. (2015). Understanding student satisfaction and dissatisfaction: an interpretive study in the UK higher education context. Studies in Higher Education, 40(2), 329-349.

Douglas, J., McClelland, R., \& Davies, J. (2008). The development of a conceptual model of student satisfaction with their experience in higher education. Quality Assurance in Education.

Duggal, M., \& Mehta, P. (2015). Antecedents to academic performance of college students: An empirical investigation. Paradigm, 19(2), 197-211.

Elliott, K. M., \& Shin, D. (2002). Student satisfaction: An alternative approach to assessing this important concept. Journal of Higher Education Policy and Management, 24(2), 197-209.

Ganyaupfu, E. M. (2013). Teaching methods and students' academic performance. International Journal of Humanities and Social Science Invention, 2(9), 29-35.

Gee, N. C. (2018). The impact of lecturers' compeencies on students' satisfaction. Journal of Arts and Social Science, 1(2), 74-86.

Haryati, T., \& Rochman, N. (2012). Peningkatkan kualitas pembelajaran pendidikan kewarganegaraan melalui praktik belajar kewarganegaraan (Project citizen). Civis, 2(2/Juli).

Jiewanto, A., Laurens, C., \& Nelloh, L. (2012). Influence of service quality, university image, and student satisfaction toward WOM intention: A case study on Universitas Pelita Harapan Surabaya. Procedia-Social and Behavioral Sciences, 40, 16-23.
Kusumajati, D. A., Ruman, Y. S., \& Oktriono, K. (2017). The influence of lecturers' competencies towards students' performance motivation: a case study at higher education. 2017 International Symposium on Educational Technology (ISET), 173-176.

Long, C. S., Ibrahim, Z., \& Kowang, T. O. (2014). An analysis on the relationship between Lecturers' competencies and students' satisfaction. International Education Studies, 7(1), 37-46.

Nahan, N. (2013). Pengaruh kualitas pengajaran, kualitas pelayanan terhadap kepuasan mahasiswa serta dampaknya pada loyalitas mahasiswa (studi pada universitas palangka raya). JSM (Jurnal Sains Manajemen), 2.

Nastiti, U. D. (2015). Pengaruh layanan mengajar dosen dan pemanfaatan fasilitas belajar terhadap kepuasan mahasiswa di universitas pasundan. Jurnal Administrasi Pendidikan, 22(1), 1-13.

Prasetyaningrum, I. D. (2009). Analisis Pengaruh Pembelajaran dan Kualitas Pelayanan terhadap Kepuasan Mahasiswa dan Loyalitas Mahasiswa (Studi Kasus pada Undaris Ungaran). Program Pascasarjana Universitas Diponegoro.

Prasetyo, H. A. (2013). Peningkatan kualitas pembelajaran matematika melalui student teams achievement division (stad) berbantuan komputer pada siswa kelas iva $s d n$ bendan ngisor. Universitas Negeri Semarang.

Sookdeo, S. S. (2016). The relationship between the utilization of student support services and overall satisfaction in medical school.

Suarman, S., Aziz, Z., \& Yasin, R. M. (2013). The quality of teaching and learning towards the satisfaction among the university students. Asian Social Science, 9(12), 1911-2017.

Suwandari, L. (2013). Pengaruh kinerja dosen, fasilitas dan komitmen organisasi terhadap kepuasan mahasiswa STMIK AMIKOM Purwokerto. JBIMA (Jurnal Bisnis Dan Manajemen), 1(1), 66-73.

Temizer, L., \& Turkyilmaz, A. (2012). Implementation of student satisfaction index model in higher education institutions. Procedia-Social and Behavioral Sciences, 46, 3802-3806.

Tessema, M. T., Ready, K., \& Yu, W. (2012). Factors affecting college students' satisfaction with major curriculum: Evidence from nine years of data. International Journal of Humanities and Social Science, 2(2), 34-44.

Wamala, R., \& Seruwagi, G. (2013). Teacher competence and the academic achievement of sixth grade students in Uganda. Journal 
of International Education Research (JIER), 9(1), 83-90.

Warta, I. W., Yudana, M., \& Natajaya, N. (2013). Pengaruh model pembelajaran kooperatif tipe STAD terhadap prestasi belajar IPS ditinjau dari konsep diri akademik siswa kelas VIII SMPN 3 Sukawati. Jurnal Administrasi Pendidikan Indonesia, 4(1).

Wilkins, S., Stephens, B. M., \& Huisman, J. (2012). Student satisfaction and student perceptions of quality at international branch campuses in the United Arab Emirates. Journal of Higher Education Policy and Management, 34(5), 543-556.
Xiao, J., \& Wilkins, S. (2015). The effects of lecturer commitment on student perceptions of teaching quality and student satisfaction in Chinese higher education. Journal of Higher Education Policy and Management, 37(1), 98-110.

Yuniarti, Y. (2014). Pengaruh kualitas pelayanan terhadap kepuasan mahasiswa program ekstensi fakultas ekonomi universitas jambi. Trikonomika, 13(1), 49-61. 